Ю. В. Думанський, П. Г. Кондратенко, М. В. Конькова, О. В. Кєтінг Донецький національний медичний університет

\title{
КОНТРОЛЬ ЕФЕКТИВНОСТІ ЗАСВОЄННЯ ПРАКТИЧНИХ НАВИЧОК ВИПУСКНИКАМИ ДОНЕЦЬКОГО НАЦІОНАЛЬНОГО МЕДИЧНОГО УНІВЕРСИТЕТУ ЗА СПЕЦІАЛЬНІСТЮ “МЕДИЦИНА”
}

\author{
Yu. V. Dumanskyi, P. H. Kondratenko, M. V. Konkova, O. V. Kietinh \\ Donetsk National Medical University
PERFORMANCE MANAGEMENT OF LEARNING PRACTICAL SKILLS SPECIALIZATION IN “MEDICINE” \\ BY DONETSK NATIONAL MEDICAL UNIVERSITY GRADUATES WITH A
}

\begin{abstract}
У статті розглянуто особливості впровадження симуляційних технологій у педагогічний процес та здійснення контролю засвоєння практичних навичок студентами, спираючись на досвід створення та використання у практично-орієнтованому навчанні Центру симуляційної медицини, що дозволяє забезпечити якісну практичну підготовку майбутніх лікарів та суттєво підвищити ефективність засвоєння практичних навичок випускниками Донецького національного медичного університету за спеціальністю “Медицина”.
\end{abstract}

Ключові слова: Центр симуляційної медицини; практичні навички; симуляційні технології; практична підготовка майбутніх лікарів.

The article deals with the peculiarities of simulation technology implementation into educational process and control of mastering practical skills by students, based on the experience of creation and use of medical simulation center at practically oriented learning, that can provide high-quality future doctors' practical training and significantly increase the effectiveness of practical skills adoption by Donetsk National Medical University graduates with a specialization in "Medicine".

Key words: Medical Simulation Center; practical skills; simulation technology; practical training of future doctors.

Вступ. Одним із пріоритетних завдань вищої медичної освіти є набуття студентами практичних навичок, які відображають готовність майбутніх лікарів до самостійної роботи. Сучасна медицина характеризується стрімким ростом високотехнологічних засобів діагностики та лікування, що приводить до збільшення кількості навичок, які повинен опанувати лікар будь-якої спеціальності. Однак останнім часом існують певні труднощі, пов'язані 3 неможливістю відтворення більшості практичних маніпуляцій із залученням реальних пацієнтів (відсутність тематичних хворих, морально-етичні та законодавчі обмеження у взаєминах між студентами та пацієнтами) [1].

Створити умови для якісної практичної підготовки лікарів дозволяє впровадження симуляційного методу навчання із застосуванням широкого спектра тренажерів та фантомів. Центри симуляційної медицини мають низку переваг, таких, як відсутність ризику для пацієнта, необмежена кількість повторів для опанування навичок, відпрацьовування дій лікаря при загрожуючих життю станах, можливість командної роботи лікарів [2]. Враховуючи вказані переваги, в Донецькому національному медичному університеті було створено Центр симуляційної медицини, який успішно функціонує на сьогоднішній день.

Оскільки метою державної атестації є встановлення відповідності рівня знань, умінь та навичок, досягнутого в результаті засвоєння освітньо-професійної програми, вимогам освітньо-кваліфікаційної характеристики, найбільш доцільно оцінювати ефективність засвоєння практичних навичок у Центрі симуляційної медицини під час проведення державної атестації лікарів.

Мета роботи - розглянути можливості впровадження симуляційних технологій у педагогічний процес та здійснення контролю засвоєння практичних навичок студентами, які навчаються за напрямом підготовки “Медицина”.

() Ю. В. Думанський, П. Г. Кондратенко, М. В. Конькова, О. В. Кєтінг 
Основна частина. Протягом навчального року кожен студент мав необмежену можливість відвідувати Центр симуляційної медицини у вільний від навчання час. Співробітник центру на вимогу відвідувача надавав йому всі необхідні для опанування практичних навичок матеріали (інструкції, алгоритми, навчальні відеофільми тощо). Крім того, згідно з наявним графіком, студенти відвідували центр разом з викладачами профільних дисциплін. Практична частина модульного контролю теж оцінювалася із застосуванням симуляційних методик.

Форма проведення практично-орієнтованого державного іспиту для студентів, які навчалися за напрямом підготовки “Медицина”, у Донецькому національному медичному університеті у 20152016 навчальному році складалася 3 двох частин. Перша частина - на клінічних базах (безпосередня робота з хворими на іспиті з клінічних дисциплін, вирішення ситуаційних задач на іспиті з гігієнічних дисциплін). Друга частина - в Центрі симуляційної медицини, комплексна для всіх дисциплін (демонстрація основних умінь та навичок згідно 3 вимогами OKX із використанням фантомів, муляжів, навчально-наочних матеріалів, рішення ситуаційних завдань).

У результаті спільної роботи завідувачів профільних кафедр було розроблено комплексні білети, які складалися 35 випадково-скомбінованих питаньнавичок з терапії, хірургії, педіатрії, акушерства та гінекології. Обов'язковим питанням у кожному білеті була серцево-легенева реанімація.

\section{Список літератури}

1. Закон України “Про вищу освіту” (Відомості Верховної Ради, 2014, № 37-38, ст. 2004) із змінами, внесеними згідно із Законом № 76-VIII від 28.12.2014 // BBP. - 2015. - № 6.

\section{References}

1. Zakon Ukrainy pro vyshchu osvitu (2015). [Higher educational Act of Ukraine]. Vidomosti Vekhovnoi Rady Verkhovna Rada Bulletin, 6 [in Ukrainian].

2. Saukh, P.Yu. (ed.) (2011). Innovatsii u vyshchii osviti:
Результати складання другої частини заносилися до протоколів проведення та оцінювання другої частини іспиту. При оцінюванні результату практично-орієнтованого державного іспиту виставлялися окремі оцінки з дисциплін, які входили до комплексу.

Вказана організація другої частини практичноорієнтованого державного іспиту дозволила не тільки об'єктивно та всебічно оцінити практичну підготовку випускників, але й досягнути економії часу.

За результатами другої частини практично-орієнтованого державного випускного іспиту, всі випускники за спеціальністю “Медицина” мали достатню практичну підготовку для продовження післядипломного навчання в інтернатурі й подальшої практичної роботи.

Висновки. Широке використання у практично-орієнтованому навчанні Центру симуляційної медицини дозволяє забезпечити якісну практичну підготовку майбутніх лікарів та суттєво підвищити ефективність засвоєння практичних навичок випускниками Донецького національного медичного університету за спеціальністю “Медицина”.

Вважаємо доцільним подальше впровадження симуляційних технологій у педагогічний процес та здійснення контролю засвоєння практичних навичок шляхом проведення комплексної другої частини практично-орієнтованого державного іспиту для студентів, які навчаються за напрямом підготовки “Медицина”.

2. Інновації у вищій освіті: проблеми, досвід, перспективи : монографія / за ред. П. Ю. Сауха. - Житомир : Вид-во ЖДУ ім. І. Франка, 2011. - 444 с.

problemy, dosvid, perspektyvy: monohrafia [Innovations within higher education: problems, experience, prospects: monography]. Zhytomyr: Vyd-vo ZhDU im. I. Franka [in Ukrainian]. 